\title{
DOS NARRADORES FRENTE A LA VIOLENCIA: RUBEM FONSECA Y FRANCISCO HINOJOSA
}

\author{
Raquel Mosqueda Rivera*
}

\begin{abstract}
RESUMEN: En este artículo se analiza el concepto de "violentización narrativa", el cual surge principalmente del reconocimiento de dos estrategias escriturales, de dos modos diferentes de abordar narrativamente el fenómeno de la violencia. Mientras que el brasileño Rubem Fonseca utiliza la ironía y la parodia para acrecentar el carácter trágico de dicha manifestación, el mexicano Francisco Hinojosa emplea estos mecanismos en un afán de "exorcizar" los efectos de la violencia. Ambos coinciden en transformar este impulso esencialmente destructivo en una propuesta estética. Dicha propuesta convoca al lector a mirar con diferente perspectiva una "fuerza" que sin duda le habita.
\end{abstract}

Palabras ClaVe: Violencia, Rubem Fonseca, Francisco Hinojosa, Parodia, Ironía, Tragedia, Farsa.

Es necesario explorar en una fuerza que tanto como la creadora, existe en el hombre: la fuerza de la destrucción.

ANDREA GUINTA

Resulta significativo, y hasta cierto punto lógico, el gran número de escritores que a últimas fechas se ocupan de la violencia; sin embargo, pocos son los que consiguen transformar este fenómeno en una auténtica propuesta estética, lograrlo no es tarea sencilla, sobre todo si se considera la gran carga negativa que conlleva este problema. Es necesario, por lo tanto, partir de la resignificación misma de la violencia como potencia que habita en cada uno de nosotros y que, pese a que puede llevar

* Centro de Estudios Literarios-Instituto de Investigaciones Filológicas, UNAM (mosquedaraquel@yahoo.com.mx). 
a la extinción misma de la especie humana, resulta uno de los medios para reconciliarnos con una naturaleza primitiva que no podemos negar $\mathrm{y}$, a un mismo tiempo, con el universo sagrado, dimensión atemporal donde los dioses parecen haberse olvidado de los hombres.

Lo anterior es factible gracias a la metamorfosis de este impulso esencialmente destructivo en fuerza de creación, en motor o eje de un proyecto artístico; tal propósito es el que evidencian los relatos del brasileño Rubem Fonseca y del mexicano Francisco Hinojosa, ${ }^{1}$ ambos consiguen, a través de diferentes vías, esta vuelta de tuerca a la que denominaremos "violentización narrativa". ${ }^{2}$ Trataré ahora de reconstruir de forma concisa los pasos que siguen cada uno de estos escritores para conformar dicho proceso.

Desde hace tiempo la violencia parece circunscribirse al espacio urbano. La marginalidad, los vicios, la miseria, la injusticia, todo aquello que conlleve un signo negativo se asocia inevitablemente a la ciudad. La literatura ha contribuido de manera importante a tal idea presentando a la metrópoli como el marco privilegiado para crear personajes y situaciones en los que la violencia alcanza su clímax. Fonseca comparte, y en gran parte promueve, la visión de una ciudad caótica donde todo lo atroz es posible. Resulta ocioso advertir que ésta es una imagen que la urbe se ha ganado a pulso; de hecho, ella misma forja los personajes que le corresponden, ya sea en el margen o dentro de su espacio, imprime una huella indeleble en cada uno de sus habitantes. Los personajes de Fonseca, ladrones, asesinos, prostitutas, policías, escritores colocados fuera del aparato oficial, responden con igual o mayor violencia a

${ }^{1}$ Respecto a Rubem Fonseca me referiré principalmente a cuentos que forman parte de su primer etapa como narrador; es decir a aquellos que aparecen en los volúmenes Feliz ano novo y $O$ Cobrador. Asimismo he seleccionado relatos de Hinojosa que, desde mi punto de vista, son paradigmáticos de la propuesta sobre violentización narrativa que a continuación expondré.

${ }^{2}$ Concepto que acusa un cierto paralelismo con el término bajtiniano de "carnavalización", en la medida en que ambos apuntan a un proceso dinámico y en esencia textual, discursivo, antes que referencial o extratextual. 
una ciudad donde la violencia es lo cotidiano; no obstante, dicha respuesta rompe con las estrategias del realismo tradicional. Para este escritor, la ciudad representa una posibilidad de escritura, de transformar la realidad en un espacio creativo, instituyendo así una nueva tradición: "o autor urbano se inscreve numa ambição literária mais ampla, em que procura um transrealismo - expressão do real além da realidade- que dê conta de uma nova experiência social urbana e, para esse fim, precisa revitalizar a linguagem poética, transgredindo as barreiras proibitivas da significação." 3 Es decir, que además de la realidad que consignan o de las causas teóricas a las que regresaré más tarde, que generan la violencia, Rubem Fonseca se inscribe en la línea de los narradores que hacen énfasis en el lenguaje con que han de expresar este mundo, para con ello lograr un impacto mayor del que podría suscitar una mera reproducción fotográfica de la realidad.

En cada uno de sus relatos pueden identificarse los múltiples rostros de la ciudad; de entre ellos sobresale el de una urbe convertida en territorio de guerra permanente:

Para falar a verdade a maré também não tá boa pro meu lado, disse Zequinha. A barra tá pesada. Os homens não tão brincando, viu o que fizeram com o Bom Crioulo? Dezesseis tiros no quengo. Pegaram o Vevé e estrangularam. O Minhoca, porra! O Minhoca! Crescemos juntos em Caxias, o cara era tão míope que não enxergava daqui até ali, e tembém era meio gago — pegaram ele e jógaram dentro do Guandu, todo arrebentado. ${ }^{4}$

Así, tras la furia de El Cobrador, personaje del relato del mismo nombre, está la ciudad-ícono con sus grandes anuncios comerciales que exhiben un bienestar que la mayoría de sus habitantes se encuentra muy

3 Karl Erik Schøllhammer, "Os cenários urbanos da violência na literatura brasileira”, en Carlos Alberto Messeder Pereira et al., Linguagens da violência, Rio de Janeiro, Rocco, 2000, pp. 248-249.

${ }^{4}$ Rubem Fonseca, "Feliz ano novo", en Feliz ano novo, Brasil, Artenova, 1975, p. 10. 
lejos de poseer y que contribuyen a exacerbar un resentimiento por largo tiempo contenido:

Top Executive Club. Você merece o melhor relax, feito de carinho e compreensão. Nossaas massagistas são completas. Elegância e discrição.

Anoto o endereço e vou para o local, uma casa, em Ipanema. Espero ele surgir, fantasiado de roupa cinza, colete, pasta preta, sapatos engraxados, cabelos rinsados. Tiro um papel do bolso, com alguém à procura de um endereço e vou seguindo o cara até o carro. Esses putos sempre fecham o carro a cave, eles sabem que o mundo está cheio de ladrões, eles também são, apenas ninguém os pega; enquanto ele abre o carro eu encosto o revólver na sua barriga. ${ }^{5}$

Podría decirse que el proceso de violentización narrativa comienza ya con la elección del espacio urbano y su transformación en territorio creativo. Tal es el caso del relato (novela corta) "A arte de andar nas ruas do Rio de Janeiro" donde, del deambular de Augusto por las calles de Río, personaje que está escribiendo un libro que se titulará "El arte de caminar por las calles de Río de Janeiro", puede inferirse que la verdadera apuesta narrativa se encuentra en el artificio que lleva a conocer una ciudad-escritura, un Río de Janeiro que sirve de pretexto para la reflexión paródica sobre la propia labor literaria y cuya construcción es paralela al proceso creativo de Augusto. Río de Janeiro surge sólo en la medida en que es escrita.

Augusto volta a escrever sobre a arte de andar nas ruas do Rio. Como anda a pé, vê coisas diferentes de quem anda de carro, ônibus, trem, lancha, helicóptero ou qualquer outro veículo. Ele pretende evitar que seu livro seja uma espécie de guia de turismo para viajantes em busca do exótico, do prazer, do místico, do horror, do crime e da miséria, como é do interesse de muitos cidadãos de recursos [...] Tambén toma cautela para que o livro não se torne um pretexto, à maneira de Macedo, para arrolar

${ }^{5}$ Rubem Fonseca, "O Cobrador", en $O$ Cobrador, Rio de Janeiro, Nova Fronteira, 1979, pp. 178-179. 
descriçiones históricas sobre potentados e instituições [...] Augusto quer iencontrar uma arte e uma filosofía peripatéticas que o ajudem a estabelecer uma melhor comunhão com a cidade. Solvitur ambulando. ${ }^{6}$

Con la elección de la ciudad como marco para su narrativa, Rubem Fonseca decide también destacar sus signos más reconocibles: la injusticia, la desigualdad, la delincuencia, el abuso y su consecuencia lógica: la violencia.

A la re-escritura de lo urbano se suma otra reelaboración: la de algunos de los elementos de la llamada cultura de masas tradicionalmente ignorados por la "alta cultura". 7 Varios son los relatos y novelas de Fonseca que pertenecen al género policiaco, género que por mucho tiempo ha sido calificado como subliteratura o como literatura para las masas por considerarlo de fácil lectura y por lo tanto popular. No pretendo entrar en una discusión que la lectura de las obras de autores como Hammett, Chandler (a quien Fonseca rinde constante homenaje) o Agatha Christie dejan sobradamente zanjada; lo que importa señalar es que Fonseca se inserta en la mejor tradición, aquella que infringe, una a una, las reglas del género y que hace de la narrativa policiaca una auténtica obra de arte. Los personajes y situaciones distan mucho del maniqueísmo clásico; sus detectives, tipos desencantados y cínicos, responden naturalmente a una ética bastante personal pero congruente con su situación, no siempre descubren al culpable, quien con frecuencia no es tan culpable y la víctima tampoco es tan inocente. No obstante esta serie de transgresiones, existe una regla de oro que no puede pasarse por alto: la ejecución de un crimen y por ende la persecución de un asesino. La abierta inclinación de Fonseca por este género (fundamentado en la violencia)

${ }^{6}$ Rubem Fonseca, "A arte de andar nas ruas do Rio de Janeiro", en Contos reunidos, organização Boris Schnaiderman, São Paulo, Companhia das Letras, 1994, p. 600.

7 Al respecto Vargas Llosa anota: "Rubem Fonseca es uno de esos escritores contemporáneos que han salido de su biblioteca a hacer literatura de calidad con materiales y recetas hurtados a los géneros de gran consumo popular", Mario Vargas Llosa, "El gran arte de la parodia”, Universidad de México, núm. 430, diciembre, 1986, p. 4. 
no es gratuita; sin duda, forma parte de un proyecto de escritura cuyo objetivo es claro: con la contravención de las pautas estéticas como punto de partida, provocar, poner en tela de juicio la idea de justicia y los códigos morales impuestos por las instituciones.

En esta misma línea se ubican relatos como "Corações solitários", en el que las emociones, los sentimientos, tan cuidadosamente prefabricados por los medios de comunicación masiva, sirven para exhibir la aparatosa banalidad de un modelo político-económico empeñado en homogeneizar cualquier espacio donde pueda asomarse un resquicio de individualidad. Así en una revista "É feita para a mulher da classe C, que come arroz com feijão e se ficar gorda azar o dela", ${ }^{8}$ un ex reportero policial tiene que usar seudónimos femeninos para escribir guiones de fotonovela y contestar el buzón sentimental. La sensiblería ramplona y el lenguaje en apariencia efectivo de estas publicaciones es magistralmente parodiado por Fonseca, quien consigue, no sólo pervertir una vez más el orden moral y social preconizado por los medios, sino transformar lo kitch en "gran arte":

Que tal a carta da ceguinha?, perguntei.

Peçanha pegou a carta da ceguinha e a minha resposta e leu em voz alta: Querido Nathanael. Eu não posso ler o que você escreve. Minha avozinha adorada lê para mim. Mas não pense que eu sou analfabeta. Eu sou é ceguinha. Minha querida avonzinha está escrevendo a carta para mim, mas as palavras são minhas. Quero enviar uma palabra de conforto aos seus leitores, para que eles, que sofrem tanto com pequenas desgraças, se mirem no meu espelho. Sou cega mas sou feliz [...] Vejamos agora sua resposta. Ceguinha Feliz, parabéns por sua força moral, por sua fé inquebrantável na felicidade, no bem, no povo e no Brasil. As almas daqueles que se desesperam na adversidade deviam se nutrir do edificante exemplo, um facho de luz nas noites de tormenta.

Peçanha me devolveu os paéis. Você tem futuro na literatura. (Ibid., pp. 26-27)

8 "Corações solitários", en Feliz ano novo, p. 19. 
Desde "fuera", Fonseca parodia un lenguaje que a su vez es parodiado por los propios personajes. Así, con la reutilización del propio lenguaje de las masas, vulnera todo un sistema, una forma de vida y lleva a cabo una crítica tanto más feroz mientras más se violentan los preceptos de esta cultura cuya artificialidad rápidamente queda al descubierto. ${ }^{9}$

De lo urbano y la masificación surgen las causas que provocan el estallido de la violencia en los cuentos de Fonseca: la desigualdad social y el resentimiento que genera la injusta repartición de la riqueza y la impune exhibición de opulencia, lujo y fatuidad en un país donde la miseria alcanza niveles desmesurados. "Feliz ano novo" da buena cuenta de lo anterior. Los tres protagonistas de este relato habitan un cuartucho sin agua, tienen tanta hambre que piensan en robar las ofrendas de comida que los macumberos dejan en las esquinas para sus dioses, todo esto sucede mientras la televisión transmite imágenes de lo que nunca podrán tener:

Pereba, você não tem dentes, é vesgo, preto e pobre, você acha que as madames vão dar pra você ? Ô Pereba, o máximo que você pode fazer é tocar uma punheta. Fecha os olhos e manda brasa.

Eu queria ser rico, sair da merda em que estava metido! Tanta gente rica e eu fudido. (p. 10)

Deciden entonces salir a robar una casa con un primer propósito: conseguir comida. Sin embargo, una vez que comienzan el asalto, estalla el resentimiento contenido y la violencia se adueña de la escena por completo:

${ }^{9}$ Utilizo el término "cultura de masas" en el sentido propuesto por José María Diez Borque: "la cultura del desposeído, que procede del aislamiento de la tradición artística y se manifiesta hostil al arte y a la actividad intelectual. Termina por explotar la indiferencia, la frustración y el resentimiento", en José María Diez Borque, Literatura y cultura de masas: estudio de la novela subliteraria, Madrid, Al-Borak, 1976, p. 35. 
Subi. A gordinha estava na cama, as roupas rasgadas, a lingua de fora. Mortinha. Pra que ficou de flozô e não deu logo? O Pereba tava atrasado. Além de fudida, mal paga. Limpei as jóias. A velha tava no corredor, caída no chão. Também tinha batido as botas. Toda penteada, aquele cabelão armado, pintado de louro, de roupa nova, rosto encarquilhado, esperando o ano novo, mas já tava mais pra lá do que pra cá. Acho que morreu de susto (p. 13).

La inversión de papeles (y con ello una primera transgresión) es clara: el poder pasa a manos de los delincuentes que aprovechan la oportunidad para volcar el odio y el desprecio que sienten por los ricos, quienes persisten en verlos sólo como un "accidente en sus vidas":

Então, de repente, um deles disse, calmamente, não se irritem, levem o que quiserem, não faremos nada.

Fiquei olhando para ele. Usava um lenço de seda colorida em volta do pescoço.

Podem também comer e beber à vontade, ele disse.

Filha da puta. As bebidas, as comidas, as jóias, o dinheiro, tudo aquilo para eles era migalha. Tinham muito mais no banco. Para eles, nós não passávamos de três moscas no açucareiro. (p. 14)

"O Cobrador", quizá el cuento más conocido de Fonseca, sigue la misma tónica: la del resentimiento por todo lo que le ha sido arrebatado, por todo lo que la sociedad, en especial los ricos, le debe: "A rua cheia de gente. Digo, dentro da minha cabeça, e às vezes para fora, está todo mundo me devendo! Estão me devendo comida, buceta, cobertor, sapato, casa, automóvel, relógio, dentes, estão me devendo" (p. 166). Comienza así una serie de asesinatos con una discriminación precisa de las víctimas: hombres en autos lujosos, tipos que salen del "club para ejecutivos", una pareja del jet-set. La furia de este cobrador no mengua tras cada crimen, por el contrario, aumenta hasta arrogarse el papel de justiciero. "Meu ódio agora é diferente. Tenho uma missão. Sempre tive uma missão e não sabia. Agora sei. Ana me ajudou a ver. Sei que se todo fodido fizesse como eu o mundo seria melhor e mais justo" (p. 181). Si 
la perpetración del crimen evidencia ya la impronta de la violencia, esto no es suficiente para el autor que se solaza en la descripción detallada de cada ejecución:

\section{Curva a cabeça, mandei.}

Ele curvou. Levantei alto o facão, seguro nas duas mãos, vi as estrelas no céu, a noite imensa, o firmamento infinito e desci o facão, estrela de aço, com toda minha força, bem no meio do pescoço dele.

A cabeça não caiu e ele tentou levantar-se, se debatendo como se fosse uma galinha tonta naos mãos de uma cozinheira incompetente.Dei-lhe outro golpe e mais outro e outro e a cabeça não rolava. (p. 173)

También en este relato la cultura de las masas juega un papel significativo ya que es de una de sus principales manifestaciones, los medios masivos de comunicación, de donde se nutre el odio de El Cobrador: "Fico na frente da televisão para aumentar o meu ódio. Quando minha cólera está diminuindo e eu perco a vontade de cobrar o que me devem eu sento na frente da televisão e em pouco tempo meu odio volta." (p. 168)

Las causas del estallido de la violencia en estos relatos resultan obvias: ¿qué sucede entonces cuando no es la desigualdad o la injusticia lo que la provoca? "Passeio noturno. Parte I", ${ }^{10}$ ejemplifica esta nueva transgresión de Fonseca. El personaje, un exitoso ejecutivo con familia, casa y un lujoso auto, sale todas las noches a atropellar al primero que se cruce en su camino.

Apaguei as luzes do carro e acelerei. Ela só percebeu que eu ia para cima dela quando ouviu o som da borracha dos pneus batendo no meio-fio. Peguei a mulher acima dos joelhos, bem no meio das duas pernas, um pouco mais sobre a esquerda, um golpe perfeito, ouvi o barulho do impacto partindo os dois ossões. ("Passeio noturno. Parte 1", p. 50)

Este cuento refleja que la violencia no es privativa de los jodidos o de los marginados, alcanza a todos porque se ha convertido quizá en la

10 "Passeio noturno. Parte I", en Feliz ano novo, pp. 49- 50. 
única vía de contacto real ante un mundo empeñado en ignorar al individuo: "A familia estava vendo a televisão. Deu a sua voltinha, agora está mais calmo? perguntou minha mulher, deitada no sofá, olhando fixamente o vídeo. Vou dormir, boa noite para todos, respondi, amanhã vou ter um dia terrível na companhia" (p. 50). Éste es uno de los puntos esenciales para aproximarse a la resignificación de la violencia a la que me he venido refiriendo. Para Romeo Tello:

El propósito de Rubem Fonseca al optar por la violencia como forma de afirmación vital y como única vía para conseguir una relación con lo sublime, es hacer evidente que bajo las circunstancias actuales de la vida social y, además, al amparo de los mecanismos políticos con que se rige ésta, el hombre sólo puede aspirar a encontrarse consigo mismo negando a los otros, y sólo puede sublimar su existencia ejerciendo acciones violentas contra cualquiera que no sea él mismo. ${ }^{11}$

Tal afirmación de ser cierta tendría que matizarse. Aunque la violencia para los personajes de Fonseca representa un medio extremo para reclamar la condición del ser individual constantemente oprimido por las instituciones (policía, familia, trabajo, etc.), también es evidente que el peligro de que se convierta en una de las manifestaciones de lo que Lipovetsky llama neonarcisismo posmoderno: la exacerbación del individuo llega a ser tan extrema que deja de representar una subversión para convertirse en una forma de homogenizarlo y, de nuevo, un método de control por parte de las instituciones hacia las cuales dirige su rechazo.

El neonarcisismo no se ha contentado con neutralizar el universo social al vaciar las instituciones de sus inversiones emocionales, también es el Yo el que se ha vaciado de su identidad, paradójicamente por medio de su hiper-inversión. Al igual que el espacio público se vacía emocionalmente por exceso de informaciones, de reclamos y animaciones, el Yo pierde sus

${ }^{11}$ Romeo Tello, La violencia como estética de la misatropía. Cuatro acercamientos a la obra de Rubem Fonseca, México, 1993, p. 108 (Tesis de Maestría, Facultad de Filosofía y Letras-UNAM). 
referencias, su unidad, por exceso de atención: el Yo se ha convertido en un "conjunto impreciso". En todas partes se produce la desaparición de la realidad rígida, es la desubstancialización, última forma de extrapolación, lo que dirige la posmodernidad. ${ }^{12}$

Es decir, en busca de la preciosa identidad se comienza a seguir una serie reglas de individualización, un verdadero manual para ser auténticos y distinguirse, separarse de ese fantasma llamado masa. Los personajes de Fonseca oscilan entre tales posiciones; por una parte, El Cobrador se acerca a la violencia primitiva que, además de constituir un reclamo de identidad, de algún modo cumple también con la función de ligarlo a la comunidad a través de los códigos de la venganza y el honor: "Estructuras elementales de las sociedades salvajes el honor y la venganza son códigos de sangre [...] El código del honor conmina a los hombres a afirmarse por la fuerza, a ganarse el reconocimiento de los demás antes de afianzar su seguridad, a luchar a muerte para imponer respeto."13 Ésta constituye sin duda la exigencia de El Cobrador, "Tão me devendo colégio, namorada, aparelho de som, respeito, sanduíche de mortadela no botequim da rua Vieira Fazenda, sorvete, bola de futebol". ("O Cobrador", p. 168. Las cursivas son mías). Por otra, los personajes de "Feliz ano novo" parecen inscribirse por completo en el hiperindividualismo contemporáneo, del cual surgen los patrones de la violencia moderna, "sin objetivo ni sentido, violencia impulsiva y nerviosa, desocializada." 14 Tras el robo y el asesinato, se dirigen de nuevo a su oscuro departamento a comer, beber y brindar por un "mejor y feliz año nuevo", nada ha cambiado, su enojo fue momentáneo, la transgresión no concluye del todo (cuando menos no en el plano ideológico). Lo que "salva" a El Cobrador de caer en este tipo de violencia es que comienza a ejercerla con un programa específico, identifica claramente al enemigo y dirige

12 Gilles Lipovetsky, "Narciso o la estrategia del vacío", en La era del vacío. Ensayos sobre el individualismo contemporáneo, Barcelona, Anagrama, 1986, p. 56.

${ }^{13}$ Lipovetsky, "Violencias salvajes, violencias modernas", en op. cit., p. 175.

${ }^{14}$ Ibid., p. 201. 
su odio; es decir, transforma su violencia en un proyecto vital: "Eu não sabia o que queria, não buscava um resultado prático, meu ódio estava sendo desperdiçado. Eu estava certo nos meus impulsos, meu erro era não saber quem era o inimigo e por que era inimigo. Agora eu sei, Ana me ensinou." (“O Cobrador", p. 182)

En cambio, la actitud del personaje de "Passeio noturno" se incluye también en ese otro tipo de violencia desubstancializada e irreflexiva, dirigida hacia cualquiera. Su origen no es la venganza sino la incomunicación. Con ella persigue sobre todo la afirmación de sí mismo frente a los otros; no obstante, su búsqueda es tan desesperada, tan extrema que termina por sucederle lo mismo que a los delincuentes de "Feliz ano novo", la violencia se convierte en parte de su rutina, con lo cual la sublevación del individuo deja de serlo, su reclamo de identidad se pierde ante el asesinato diario, ante la transgresión continua: "cuando ya no hay un código moral para transgredir, queda la huida hacia delante, la espiral extremista, el refinamiento del detalle por el detalle, el hiperrealismo de la violencia, sin otro objetivo que la estupefacción y las sensaciones instantáneas." 15

A pesar de tales diferencias, todos los relatos de Fonseca que suscriben esta temática parecen perseguir un fin específico: emplear la violencia como reclamo de humanización; dicho de otro modo, matar, violar o destruir se convierte en el único medio con que cuentan estos personajes para que se les reconozca su humanidad.

Con el fin de lograr lo anterior Fonseca lleva a cabo una inversión más, ya que mientras en la antigüedad se elegía a una víctima de entre los animales cuyas características de algún modo recordaran rasgos humanos; en sus cuentos, son personajes como El Cobrador quienes buscan recuperar estos rasgos de los que poco a poco han sido despojados y lo logran sólo en la medida en que animalizan a sus víctimas, accediendo a lo que Bolívar Echeverría define como violencia destructiva:

${ }^{15}$ Ibid., p. 205. 
"la que persigue la abolición o eliminación del otro como sujeto libre, la que construye al otro como enemigo, como alguien que sólo puede ser aniquilado o rebajado a la animalidad."16

Rubem Fonseca nos confronta con una doble paradoja: mientras que la posibilidad de ser reconocido por los demás como un ser humano se consigue sólo mediante la animalización-aniquilamiento del otro, tras su reclamo, El Cobrador completa el ritual con una especie de retorno a la "naturaleza salvaje" del hombre:

Quando satisfaço meu ódio sou possuído por uma sensação de vitória, de euforia, que me dá vontade de dançar — dou pequenos uivos, grunhidos, sons inarticulados, mais próximos da música do que da poesia, e meus pés deslizam pelo chão, meu corpo se move num ritmo feito de gingas e saltos, como um selvagem, ou um macaco. ("O Cobrador", p. 176)

¿Qué fin persigue esta subversión constante, esta serie de interpretaciones propuestas por Fonseca? Ya mencioné que algunas de éstas no funcionan del todo en el ámbito ideológico ("Feliz Ano Novo", "Passeio noturno") pues no es en este terreno, al menos no principalmente, donde radica la verdadera apuesta. La temática violenta, punto de partida, pronto pasa a segundo plano para dar cabida al espacio en el cual la violencia se transforma y encuentra su resignificación: el lenguaje.

O mais importante a respeito da literatura que tematiza a violência e que ela se articula na fronteira de sua capacidade expressiva e a transgressão deste limite é idêntica à capacidade de ressimbolizar aquilo que foi excluído pela lei do discurso, iniciando uma comunicacão poética entre o real e o ficcional, entre o verdadeiro e o falso, entre o representado e o imaginado, entre o universal e o particular e entre o público e o privado. ${ }^{17}$

16 Bolívar Echeverría, "Violencia y modernidad", en Adolfo Sánchez Vázquez [ed.], El mundo de la violencia, México, FFyL-UNAM/FCE, 1998, p. 370.

${ }^{17}$ Schøllhammer, op. cit., p. 250. 
Así la auténtica transgresión reside en el artificio narrativo en el cual se evidencia que más allá de dar cuenta de un mundo sórdido y violento, lo que Fonseca propone es hacer de la violencia una nueva forma de mirar e interpretar al mundo, una manera de enfrentar la vida, una actitud.

Esta actitud se distingue en "O Cobrador" ya desde el título mismo y se confirma con el inicio del relato. La simbolización, parte fundamental del artificio narrativo, surge en la forma de una gran boca, ícono que para El Cobrador está asociado con el bienestar y la riqueza e incluso podría inferirse que lo que desata su rabia es un insoportable dolor de muelas:

Na porta da rua uma dentadura grande, embaixo escrito Dr. Carvalho, Dentista. Na sala de espera vazia uma placa, Espere o Doutor, ele está atendendo um cliente. Esperei meia hora, o dente doendo[...]

Uma injeção de anestesia na gengiva. Mostrou o dente na ponta do boticão: A raiz está podre, vê?, disse com pouco caso. São quatrocentos cruzeiros.

Só rindo. Não tem não, meu chapa, eu disse. (“O Cobrador”, p. 105)

Tal intención se acentúa con cada acto de El Cobrador; sin embargo, cuando se está a punto de etiquetarlo como uno más de los muchos asesinos a sangre fría o como un loco, se tropieza con un hecho inesperado, con una especie de trampa destinada a vulnerar, no sólo el código ético en el que se refugia el lector sino sobre todo una serie de convenciones estéticas: El Cobrador se define a sí mismo como un poeta.

$\mathrm{Na}$ casa de uma mulher que me apanhou na rus. Coroa, diz que estuda no cólegio noturno. Já passei por isso, meu cólegio foi o mais noturno de todos os cólegios noturnos do mundo, tão ruim que já não existe mais, foi demolido. Até a rua onde ele ficava foi demolida. Ela pregunta o que eu faço e digo que sou poeta, o que é rigorosamente verdade. Ela me pede que recite um poema meu. Eis: Os ricos gostam de dormir tarde/ apenas porque sabem que a corja/ tem que dormir cedo para trabalhar de manhã/ Éssa é mais uma chance que eles/ têm de ser diferentes:/ parasitar,/ 
desprezar os que suam para ganhar a comida,/ dormir até tarde,/ tarde/ um dia/ ainda bem/ demais. (“O Cobrador”, p. 169)

El proyecto de vida que se trazará más adelante tiene su antecedente en un proyecto de escritura, en una especie de manifiesto poético. Hay algo más, el personaje parece ser el único que realmente entiende el significado de la justicia. No mata a la prostituta porque está igual de jodida que él, tampoco a un negro que le reclama un periódico ya que, también como él, tiene pocos dientes. Si en un principio tales asociaciones (asesino-poeta, asesino-justo) parecen contradictorias y excluyentes, tras las acciones y argumentos del personaje deben reconocerse como posibles e incluso razonables. Fonseca ha conseguido involucrar al lector en la lógica de El Cobrador, de aquí a justificar su comportamiento hay sólo un paso. Lo anterior, además de ratificar la postura crítica del autor, "dirigida a mostrar lo decepcionante de una sociedad en la que los únicos seres profundamente sensibles han renunciado a todos los caminos de comunicación y convivencia en que nos gustaría seguir empeñando nuestra esperanza", ${ }^{18}$ reafirma que la verdadera subversión se inscribe en la conciencia con la cual el escritor construye un proyecto narrativo con la sistemática violentización de fundamentos estéticos como base.

Las varias posibilidades narrativas de la violencia en los cuentos del escritor brasileño sirven como punto de partida para indagar en otra visión, una propuesta distinta que retoma la violencia como base de un plan de escritura y que de alguna forma puede considerarse como la contraparte, el doble simiesco e, incluso, como la parodia de todo lo que hasta aquí se ha dilucidado. Se trata de los cuentos de Francisco Hinojosa, autor mexicano que hace de la ironía el espejo desde el cual la violencia refleja uno más de sus muchos rostros.

Contrario a lo que sucede con Rubem Fonseca, la obra de Hinojosa no comienza dicha resignificación con la elección de la ciudad como

${ }^{18}$ Tello, op. cit., p. 177. 
espacio narrativo, ni con la denuncia de las injusticias sociales; sus personajes, con ser marginales, lo son de modo diferente; es decir, la violentización narrativa se lleva a cabo de modo inverso. Mientras que en la obra del brasileño cada paso del proceso contribuye a formular una nueva visión de la violencia, en los cuentos del narrador mexicano dicha visión representa el punto de partida para crear personajes, situaciones e historias que confirman a la ironía como uno de los principales indicios de violentización dentro del texto.

Puede afirmarse que el principal modo en que la ironía ejerce la violencia es a través de su insistente empeño en destruir cualquier tipo de certidumbre, de certeza: "la visión irónica pone en evidencia inesperados pliegues y vertientes donde no es la certeza sino la incertidumbre y la incongruencia, no el reconocimiento sino el sinsentido lo que quiere brotar como lo indomable y el vértigo que siempre, por más que los ignoremos, nos acosan." 19 Entre otros, es precisamente este rasgo, que impone una realidad distinta y que designa a la ironía como un modo privilegiado de practicar la violencia, el que lleva a calificar a Hinojosa como un ironista. Si como señala Víctor Bravo en "el corazón de la ironía se encuentra la experiencia de la alteridad: la floración de las formas de la exterioridad silenciadas o negadas por el orden y lo real", ${ }^{20}$ sin duda la mayoría de los relatos del escritor mexicano se inscriben en esta tendencia; cada uno contraviene cuidadosamente una realidad y se ocupa de crear otro orden que, en la mayoría de los casos, raya en el caos y en el absurdo.

Ya desde los motivos mismos que la originan, contrarios a las causas sociales expuestas en los cuentos de Rubem Fonseca, se puede advertir el papel preponderante que la ironía desempeñará en la construcción del relato.

19 Víctor Bravo, Figuraciones del poder y la ironía. Esbozo para un mapa de la modernidad literaria, Caracas, Monte Ávila Editores/CDCHT-Universidad de los Andes, 1997 (Estudios), p. 9.

${ }^{20}$ Ibid., p. 90. 
La "evidente superioridad espiritual" de una familia provoca el odio de los Millán, sus vecinos de enfrente, los cuales les declaran una guerra a muerte:

La guerra sí parecía en serio. Al menos más en serio que otras veces. Los Millán estaban decididos a todo, a exterminarnos a como diera lugar. Sus rostros, tras los arcos y los rifles, estaban hinchados de coraje, de desesperación por no poder tirar de un solo gatillazo mil municiones, de un solo jalón mil flechas encendidas, por no poder convertir nuestro departamento en un bosque en llamas que consumiera hasta la última huella de nuestra evidente superioridad espiritual. ${ }^{21}$

En "Nunca en domingo" el asesinato surge en un intento por alterar el orden asfixiante de una vida familiar que amenaza con repetirse eternamente.

1. Me repugna la gorda que vive arriba.

2. Diana me informa que va a salir con los niños al parque. Para que no haya pleito, finjo interesarme: "abrígalos”, le digo. “Con este calor!”, se enfurece conmigo.

[...] 10. “¿Y hoy qué vamos a hacer?” Lo dice con una pequeña dosis de esperanza que me enternece

11. "Que los niños vean la tele, tú prepara algo de comer y déjame a mí decidir qué hago con mi tiempo", respondo de buenas maneras. (pp. 8384)

La intención crítica, otra característica que relaciona la ironía con la violencia, adquiere un aspecto diferente al ya mencionado en la obra de Fonseca, dado que Hinojosa, además de exhibir el deterioro y la falsedad de instituciones, valores, emociones, etc., al anteponer a este propó-

${ }^{21}$ Francisco Hinojosa, "A la sombra de los caudillos en flor", en Negros, héticos, hueros, México, Ediciones Sin Nombre/Juan Pablos Editor, 1998, p.16. A partir de esta nota las citas de los textos de Hinojosa serán tomadas de esta compilación y sólo se indicará entre paréntesis el título y la página. 
sito la actitud irónica, infringe una nueva ruptura a un mundo ya de por sí fragmentado; tal proceso de descomposición culmina donde empezó: en el vértigo del absurdo y el sinsentido.

Si en los cuentos de Rubem Fonseca, los personajes se revelan ante una realidad que los margina, los personajes de Francisco Hinojosa, en cambio, deciden adelantarse a la realidad y ser ellos quienes instauren un universo propio que deja fuera todo aquello que no cumple con su lógica:

Al fin desayunamos los cuatro y yo bajé unos setecientos gramos. Les parecía a todos tan increíble que no dejaron de interrogarme: pensaban que yo tenía un secreto para bajar de peso después de comer. Les dije que no, que yo así era (aunque la verdad nunca me había pasado algo igual). El gran Enrique se enojó y la muchacha llamada Margarita también. La Juliana y yo, mientras, nos tumbamos un rato en la yerba para retozar. Y así fue como le empezaron a salir a ella gusanos de sus heridas [...] a la hermosa Margarita se le ocurrió que lo mejor era distraerse y dejar que todo pasara. ("Relato de espantos en tierra nevada", p. 205)

La imposición de otra realidad a través de la lógica del absurdo, las peculiares causas que suscitan la violencia, el uso de un lenguaje artificioso y falso que intenta encubrir la intención crítica, todo visto a través de un inmenso espejo irónico conforman este proyecto narrativo que podría resumirse en un doble movimiento, en una especie de círculo vicioso; es decir, ahí donde la violencia pretende enmascararse con el rostro de la ironía, es ésta misma quien se ocupa de denunciarla, de exhibirla para después ocultarla de nuevo tras uno de sus propios mecanismos.

Dos son los medios principales con los cuales Hinojosa conjura los efectos de la violencia en sus historias: la parodia y el humor; por una parte, tanto en su carácter de burla como de homenaje, la parodia se ocupa de - hasta cierto punto- paliar la creciente incertidumbre creada por la ironía; por otra, pese a que la risa estalla continuamente debe hacerse hincapié en la particularidad de esta risa a medio camino entre el desencanto y la mofa. 
Mientras en los cuentos de Francisco Hinojosa la ironía se exhibe de forma incluso aparatosa, la sutileza, la ambigüedad y el artificio son los adjetivos que definen el peculiar modo en que Rubem Fonseca expresa la intención irónica. ${ }^{22}$ Tales atributos no hacen sino resaltar la efectividad de su empleo, ya que evidentemente: "La ironía está en su máximo de eficacia cuando menos presente está, cuando está casi in absentia". ${ }^{23}$

Pese a que ambos autores pueden ser calificados como ironistas, existen varios aspectos en los cuales difieren. Al igual que en Hinojosa, en Fonseca la ironía se percibe como un ejercicio de la alteridad, sólo que en un sentido distinto al ya revisado en el autor mexicano. Si en los relatos de este último la ironía surge de la creación de situaciones evidentemente absurdas, en los cuentos de Fonseca el absurdo se revela como el rostro cotidiano de la realidad. Asimismo, sus personajes siempre son los otros, los que han quedado fuera, por lo tanto, su sola existencia quebranta un orden sin que ellos tengan que llevar a cabo acción alguna; de tal suerte, Fonseca obliga a la realidad a reconocer su propia sinrazón, a volver la vista hacia la otredad.

De la contravención de aquellos presupuestos irónicos (cuya práctica resulta tan constante en Hinojosa) como son: "el conjuro de la ingenuidad, la artificiosidad manifiesta y la potenciación de los sobrentendidos", ${ }^{24}$ se desprenden otros de los recursos que identifican el proceso de violentización. Sin duda la narrativa de Fonseca exige lectores que

${ }^{22}$ La "sutileza" irónica funciona aquí en el sentido propuesto por Ballart: "La estrategia en orden a la cual disponen su significado las obras irónicas es, de hecho, un oscilar constante entre la opacidad y la transparencia, oscilar que las hace rehuir por igual el mensaje explícito, que volvería gratuito el uso de la ironía, como la alusión demasiado oscura, que se negaría a la interpretación incluso del lector más avisado", Pere Ballart, Eironeia. La figuración irónica en el discurso literario moderno, Barcelona, Quaderns Crema, 1994, p. 427.

${ }^{23}$ Roland Barthes, S/Z, trad. Richard Miller, Nueva York, Hilland and Wang, c. 1974, p. 191.

${ }^{24}$ Ballart, op .cit., p. 366. 
hace tiempo dejaron atrás cualquier atisbo de inocencia (literaria al menos); ya he señalado que el artificio en estos relatos radica más bien en la forma de encubrirlo, lo mismo puede decirse respecto del último punto, dar por hecho o sobrentender cualquier cosa implica un grave riesgo, puesto que uno más de los atributos de estas historias es su indiscutible capacidad de tomar por sorpresa al lector, cumpliendo con otra de las premisas fundamentales de la ironía: "el ironista es siempre un amante de la paradoja y de la analogía, de buscar relaciones inéditas entre las cosas que demuestren que el mundo es tan vario y mudable como los individuos que lo interpretan." 25

Así, mientras la ironía en Hinojosa pretende enmascarar la violencia (al menos en un primer movimiento) en Fonseca, la ironía pone en marcha sus mecanismos más finos, explota al máximo sus elementos de manera tal que desde la primera línea la violencia toma por asalto al lector. Con dicha exacerbación pone de manifiesto una serie de discursos engañosos (dentro y fuera del hecho literario), al mismo tiempo que lleva a cabo una crítica certera e implacable de la sociedad contemporánea.

En cambio, y como consecuencia lógica del manejo singular de la ironía, surge la parodia: "la parodia es, a plenitud, uno de los procesos de la conciencia irónica, la percepción desde la identidad, de la incongruencia de lo real, de la dialéctica de la identidad y la diferencia, de la identidad y la negación que se encuentra en las fibras mismas de lo instituido"; 26 ironía y parodia convergen en un mismo propósito: poner al descubierto la falsedad y retórica de los discursos hegemónicos, tomando en cuenta que:

Fonseca no está parodiando lo que ocurre en la sociedad (el objeto de la parodia no son las prostitutas asesinadas, los niños indigentes rociados de gasolina y quemados durante las noches, los matones a sueldo, los policías ojerosos que huelen a sudor y tabaco), sino la interpretación de la

${ }^{25}$ Ibid., p. 414.

${ }^{26}$ Bravo, op. cit., p. 118. 
desigualdad como un discurso que viene desde arriba y que es inyectado en los individuos de maneras diversas. ${ }^{27}$

La mayor parte de las formas utilizadas por la parodia (reescritura, intertextualidad, degradación, afirmación) se dirigen principalmente contra las convenciones y los cánones literarios, así la escritura y el proceso de creación son dos de los blancos privilegiados: escritores excéntricos que deciden colgarse una grabadora al cuello ("Pierrô da caverna"); escritores que no escriben ("Agruras de um jovem escritor"); libros que encarnan una burla ("O livro de panegíricos"); escritura dentro de la escritura ("A arte de andar nas ruas do Rio de Janeiro"); reflexión sobre la propia postura frente al quehacer literario ("Intestino grosso") y, llevando la parodia al límite, escritores apócrifos en busca de venganza: "Seja um escritor respeitado e admirado pelos seus amigos, seus vizinhos, sua família, sua namorada. Eu escrevo para você o livro que você quiser. Poesias, romances, contos, ensaios, biografias. Sigilo absoluto. Cartas para Ghostwriter" (“Artes e ofícios”, p. 88). ${ }^{28}$ La degradación de la escritura es notoria; cada uno de estos relatos se ocupa de desacralizar convenciones literarias: la originalidad sin artificios, el mito del genio creativo, la gratuidad de la escritura, la imaginaria cuota que el escritor tiene que rendir si quiere dedicarse a las letras: "João dizia que havia um ônus a pagar pelo ideal artístico: pobreza, embriaguez, loucura, escárnio dos tolos, agresão dos invejosos, incompreensão dos amigos, solidã, fracasso." (“A arte de andar nas ruas do Rio de Janeiro”, p. 594) y por supuesto, las grandes pretenciones de todo autor de escribir una "obra maestra". Más allá de reconocer algunos rasgos autobiográficos en estos relatos, interesa subrayar la abierta intención que traducen: provocar, infringir rupturas insuperables en nuestra visión del mundo. Si bien por caminos distintos Rubem Fonseca, al igual que Francisco Hino-

27 Tello, op. cit., p. 94.

${ }^{28}$ Rubem Fonseca, “Artes e ofícios”, en O buraco na parede, São Paulo, Companhia das letras, 1995. 
josa, pone a prueba cada una de nuestras certezas, a diferencia de éste, su burla no se enfila hacia la sensatez y el sentido común, sino hacia la falsedad, la incongruencia de discursos e instituciones en los que ya nadie puede creer.

Del efectismo, fruto de la economía del lenguaje, y de la estrecha relación que mantiene Fonseca con las manifestaciones de la llamada cultura de masas, entre ellas el cine, surge a su vez otra de las piezas que complementan el proceso de violentización, me refiero a lo horroroso ${ }^{29}$ como táctica y categoría estética de dicho procedimiento.

Si de la fuerza de las imágenes depende en gran medida el efecto buscado, entonces ¿qué mejor vía que lo repugnante para provocar una doble reacción?, es decir, mientras que por una parte la violencia de estas imágenes desconcierta al lector, por otra, la plasticidad de las mismas le fascina de modo tal que le impide apartar la mirada:

A velha tava no corredor, caída no chão. Também tinha batido as botas. Toda penteada, aquele cabeão armado, pintado de louro, de roupa nova, rosto encarquilhado, esperando o ano novo, mas já tava mais pra lá do que pra cá. Acho que morreu de susto. Arranquei os colares, broches e anéis. Tinha um anel que não saía. Com nojo, molhei de saliva o dedo da velha, mas mesmo assim o anel não saía. Fiquei puto e dei uma dentada, arrancando o dedo dela. ("Feliz ano novo", p. 13)

Sin duda esta relación de rechazo-fascinación se enmarca ya en el ámbito de la recepción. Con el lector como eje, la transición del terreno artístico al de lo ético y viceversa es casi simultánea, el círculo se cierra. La violencia aprovecha así una respuesta que ella misma provocó para retornar a su naturaleza sagrada.

29 Debo aclarar que uso este término en su sentido más inmediato: como "algo" que provoca nuestro rechazo e incluso perturbación, que busca: "producir en el lector un estremecimiento que él mismo anhela experimentar; quiere enseñarle los abismos a cuyo borde se coloca voluntariamente", Wolfang Kayser, Lo grotesco. Su configuración en pintura y literatura, Buenos Aires, Nova, 1964, p. 169. 
De todo lo anterior se desprenden dos consideraciones; la primera de ellas consiste en destacar cómo Fonseca logra concertar el equilibrio justo entre los diversos recursos de los que echa mano: a lo horrendo y al efectismo opone la economía del lenguaje, con lo cual evita caer en un tremendismo poco auténtico. Con la ironía como contrapeso y sin que por ello se debilite, antes bien cobre fuerza, la crítica social trasciende la denuncia fácil; finalmente, la parodia se ocupa, a un mismo tiempo, de encubrir/descubrir el artificio con el que se intenta enmascarar la violencia.

Resta señalar lo obvio: si bien estos relatos parecen implicar una irremediable condena de silencio impuesta por la violencia, es Fonseca con su propia escritura quien supera el "maleficio": si una historia como la de "O Cobrador" puede ser narrada, entonces todo puede contarse:

A literatura que comunica ou tenta comunicar a violência modifica-a sempre que reencena a comunicacão impossível, pois a reecenação representativa atua no sentido de resimbolização do conteúdo excluído. Comunicar a violência é como tentar superar o silêncio da não-comunicacão violenta, ou seja, aquele instante em que as palavras cedem e abrem lugar para a violência. Comunicar a violência é uma maneira não de divulgar a violência, mas de de ressimbolizá-la. ${ }^{30}$

Hasta aquí las obras estudiadas parecen seguir derroteros por completo diferentes: mientras en los relatos de Rubem Fonseca la violencia se erige como un reclamo de humanidad, en la obra de Francisco Hinojosa en cambio, deviene en factor cotidiano, la consecuencia lógica del absurdo que rige su universo narrativo; en el primero la violencia se exhibe sin reservas; en los cuentos del segundo, por el contrario, urde mil maneras de simularse. La ironía constituye un primer punto de confluencia (pese al modo distinto de abordarla); no obstante, la aproximación más importante reside en el efecto que ambas propuestas buscan

30 Schøllhammer, op. cit., p. 252. 
provocar en el lector. Para definir esta reacción se apela a vocablos como perplejidad, desconcierto, horror, incertidumbre, confusión, etc., emociones todas que pueden resumirse en dos términos: terror y compasión, efectos que según Aristóteles, conducen a una "cierta liberación del peso de la realidad", es decir, a la catarsis.

La convergencia fue momentánea, para completar la experiencia catártica hace falta optar por una de las dos vías señaladas también por Aristóteles. ${ }^{31}$ La elección es clara, el universo sórdido y realista de Fonseca se corresponde indudablemente con una perspectiva trágica (tanto de la realidad como de la literatura misma). Compete entonces a los alucinantes mundos creados por Hinojosa transitar por la senda del desatino y el humor, me refiero por supuesto al enfoque cómico.

Así se encuentra en la configuración de los héroes fonsequianos los fundamentos de la perspectiva trágica a la que he hecho referencia; en este sentido, importa objetar lo expresado por Romeo Tello:

En todas las literaturas, el héroe ha sido un personaje que posee una carga ética inherente a su ser, y esa carga ética debe ser clara, nunca ambigua, pues el héroe es pensado como la síntesis de las virtudes humanas; así tenga que padecer en su historia personal, su padecimiento es presentado como necesario para mantener el equilibrio social. ${ }^{32}$

Tal aseveración deja fuera las contradicciones éticas entre las cuales oscila y que, sin duda, definen al héroe trágico, contradicciones que

31 Esta consideración se desprende de las definiciones señaladas por Aristóteles en su Poética según las cuales: "La comedia, como dijimos, es reproducción imitativa de hombres viles o malos, y no de los que lo sean en cualquier especie de maldad, sino en la maldad fea, que es, dentro de la maldad, la parte correspondiente a lo ridículo. $\mathrm{Y}$ es lo ridículo una cierta falla y fealdad sin dolor y grave perjuicio", p. 7; y en cuanto a la tragedia la refiere como "imitación de varones en acción, no simple recitado; e imitación que determine entre conmiseración y terror el término medio en que los afectos adquieren estado de pureza", p. 9, Aristóteles, Poética, $2^{\mathrm{a}}$ ed., versión de Juan David García Bacca, México, UNAM, 2000 (Bibliotheca Scriptorvm Graecorvm et Romanorvm Mexicana).

${ }^{32}$ Tello, op. cit., p. 144. 
los personajes fonsequianos comparten. Distintos signos sustentan esta hipótesis, en primer lugar hay que insistir en la obstinación con que estos seres se apartan de un encasillamiento maniqueo, no son buenos ni malos, sino en extremo humanos; la alternancia de papeles, su conversión clara de víctimas a verdugos y viceversa, retoma una cualidad esencial de la tragedia:

Nadie en suma, encarna la esencia del opresor o la esencia del oprimido; las interpretaciones ideológicas de nuestra época son la traición suprema del espíritu trágico, su metamorfosis pura y simple en drama romántico o en western americano. El maniqueísmo inmóvil de los buenos y de los malos, la rigidez de un resentimiento que no quiere soltar a su víctima cuando la tiene entre las manos, ha sustituido por completo las oposiciones alternativas de la tragedia, sus mudanzas perpetuas. ${ }^{33}$ (Las cursivas son mías)

Asimismo asumir, convertirse precisamente en ese otro que se dice odiar, se incluye entre dichas mudanzas.

René Girard afirma que, al igual que en la tragedia griega, la violencia es fruto de la pérdida de las diferencias; así, en busca de una identidad propia, el hombre, inmerso en la dinámica de la violencia, termina por perderla, ${ }^{34}$ lo cual concuerda con lo que he venido expresando, la exigencia de identidad como propósito fundamental en la narrativa de Fonseca. Oponerse al sufrimiento, no conformarse con el destino impuesto por los dioses (en este caso por el dinero y las convenciones sociales, inefables dioses del mundo contemporáneo), característica singular del héroe trágico, se suma a los anteriores atributos. El gesto de estos personajes decididos a cobrárselas, a burlar a los dioses, ¿no es acaso el mismo de Edipo o el de Hamlet? El fracaso de su rebelión refuerza el sino trágico; nunca serán suficientes los ricos asesinados por El Cobrador para restaurar la justicia en el mundo; las transgresiones de

${ }^{33}$ René Girard, La violencia y lo sagrado, Barcelona, Anagrama, 1983, p. 156.

${ }^{34}$ Cfr., ibid. 
"Pierrô da caverna" no cuentan porque nadie las conoce; el crimen premeditado y exacto del personaje de "Passeio noturno" tampoco logrará restablecer una comunicación rota desde hace tiempo, pese al fuego, los buitres devoran las entrañas de Prometeo. ${ }^{35}$

Algunos de los aspectos ya analizados participan del perfil trágico: la ineficacia de las palabras para cumplir con su función primordial; la paradoja de que sean escritores o poetas los mismos que han declarado sospechoso y artificial todo lenguaje; o el hecho de que asesinos y pederastas se revelen a un tiempo como seres profundamente sensibles; la tragicidad de tales postulados queda a la vista. Por último, la ironía (cuya naturaleza es en sí misma trágica) consolida este perfil; a fin de cuentas, valerse de ella o bien intensifica la crítica, o bien encierra una nueva violencia (tragicidad): la de no poder llamar a las cosas por su nombre. ${ }^{36}$

Héroes en sentido inverso, ${ }^{37}$ provocan, en su calidad de víctimas, compasión, entendida ésta en el sentido propuesto por Aristóteles, los compadecemos porque cualquiera de nosotros podría estar en su lugar; por el contrario, como verdugos, suscitan un abierto terror; lo que sus actos reflejan es la supremacía de la violencia, especie de potencia sobrenatural que no podemos controlar y que amenaza con sumergirnos en el caos. ${ }^{38}$ Añadiré además algo que se intuye desde un primer acercamiento a la obra de Fonseca, la certeza de tener delante una obra abier-

${ }^{35}$ Esta conjetura encuentra apoyo también en la teatralidad de ciertos pasajes: el baile de El Cobrador hacia el final de cada asesinato, las lágrimas de Pierrot en la clínica (nombre de personaje de pantomima además) o el escenario de "Nau catrineta" por poner sólo unos ejemplos.

${ }^{36}$ Se diría que el ironista es un hipócrita obligado a serlo y que encuentra en la ironía el medio para vengar tal imposición.

${ }^{37}$ Considero que los personajes de Fonseca no son antihéroes más bien "héroes contemporáneos", conformados a la medida exacta de la sociedad que los genera.

${ }^{38}$ La percepción del caos remite también al sentido trágico: "La tragedia encarna una experiencia del caos, y el único cosmos que el poeta trágico puede ofrecer con seguridad como compensación es el cosmos de su creación, en que se integran la trama, personajes, diálogos e ideas." Eric Bentley, La vida del drama, México, Paidós, 1998 (Studio 23), p. 271. 
tamente moral; por un lado, lo que sus cuentos advierten — casi de la misma manera en que el Oráculo de Delfos a Edipo- es el peligro de ceder ante la violencia y la sinrazón, fatal destino del hombre contemporáneo, por otro, trascender este estigma a través de la experiencia estética constituye también un valor moral.

Ya se mencionó que existe otra alternativa además de la trágica mediante la cual el hombre puede hacer frente a la incertidumbre y la perplejidad; me refiero a lo cómico y a una de sus expresiones fundamentales: la farsa, núcleo substancial en la narrativa de Francisco Hinojosa. Si bien se encuentra en la obra del escritor mexicano la crítica hacia ciertos aspectos de la realidad, empero, la forma irónica y burlona que elige para llevarla a cabo ocasiona que no consiga ser tan efectiva como la crítica directa y descarnada presente en el quehacer de Fonseca; se alegaría entonces que la provocación hacia el lector parte primordialmente de los principios estéticos que sustentan el armazón de este proyecto narrativo; si bien el proceso antes descrito, mediante el cual nos transformamos en lectores irónicos se repite, no obstante, como ya se indicó, gracias al empleo del humor y de la parodia, la creciente violencia, fruto del ejercicio de la visión irónica, sufre una cierta relativización. El requerimiento al receptor se cifra entonces en el artificio que subyace en toda su narrativa, hablo del esperpento. ${ }^{39} \mathrm{El}$ "enfoque distorsionado y caricaturesco de una realidad también burlesca", ${ }^{40}$ presupuesto básico del esperpento, permea casi todos los cuentos de Francisco Hinojosa.

${ }^{39}$ Retomo la definición de esperpento formulada por Rodolfo Cardona y Anthony N. Zahareas: "el esperpento como género o filtro, como estilo deformante, como perspectiva alejada, como forma teatral, como tema de lo absurdo, como elaboración de la historia y como actitud relacionada con la tradición de lo grotesco", en Visión del esperpento; teoría y práctica en los esperpentos de Valle Inclán, Madrid, Castalia, 1970 (La lupa y el escalpelo), p. 39.

${ }^{40}$ Patricio Esteve, "Introducción al esperpento (La pipa de Kif)", en Ramón M. del Valle Inclán, 1886-1966. Crítica e interpretación. Estudios reunidos en conmemoración del centenario, La Plata, Facultad de Humanidades-Universidad de La Plata, 1967, p. 282. 
La construcción de sus personajes también se guía por este principio: hombres que adelgazan cada vez que comen o que se despedazan poco a poco, mujeres resbaladizas o que sudan gusanos, en fin toda una gama de seres absurdos, ridículos, grotescos. Es precisamente con esta deformación extrema que se tiende el vínculo desde el absurdo hacia el espacio del lector:

Porque lo grotesco representa nuestro contacto con lo desatinado y lo irracional; aunque su efecto pueda llevarnos del disgusto al terror, del pavor a la risa, nos presenta un mundo monstruoso y misterioso que se resiste a que nadie trate de arreglar sus componentes de acuerdo con cualquier esquema racional. ${ }^{41}$

Pese al "ritual de exorcismo" que se ha llevado a cabo a través de la risa, tal contacto sugiere que las señales de la violencia perduran.

A su vez, de la persistencia del absurdo y del desatino deviene la configuración fársica. ${ }^{42}$ Ciertamente la narrativa de Francisco Hinojosa tiende hacia esta dirección, aparte de lo irracional de sus universos, sus personajes actúan conforme a mecanismos fársicos: "El hombre, según la farsa, sea o no sea uno de los animales más inteligentes, es ciertamente un animal, y no uno de los menos violentos. Por poca inteligencia que posea puede dedicarla, precisamente a la violencia, a urdir la violencia, o a soñar con ella." ${ }^{43}$ Otros aspectos privativos de este género como la dialéctica entre la agresión y la impertinencia, así como el intento por evadirse de cualquier forma de responsabilidad moral (contrario a lo expresado respecto al punto de vista trágico), ${ }^{44}$ se verifican en los relatos del volumen Negros, héticos, hueros. Aunado a esto se distinguen las impresiones resultantes de la deformación esperpéntica que la risa

\footnotetext{
${ }^{41}$ Cardona y Zahareas, op. cit., p. 49.

${ }^{42}$ Cfr. Bentley, op. cit., p. 271.

43 Ibid., p. 232.

${ }^{44}$ Ibid., p. 226.
} 
consigue apenas atenuar: "siendo así que frecuentemente la risa sirve para aminorar el horror y la perplejidad, y para que la pesadilla se haga más llevadera." ${ }^{45}$ En conjunto se cumple el efecto buscado por el propio autor: "La violencia siempre ha estado detrás de mi escritura... Y otro eslabón sería el humor. Si hay una intención en lo que escribo, es la de provocar la risa amarga en el caso de los cuentos para adultos y una risa desenfadada en los niños. Una risa ante la violencia, ante la muerte." $" 46$

Sin duda, lo que esta particular risa delata constituye un punto más de divergencia con la obra de Fonseca: reír como un artilugio para atenuar el horror, "La risa ante algo grotesco no es igual que la risa ante algo cómico, y el horror desconcertado frente a lo grotesco no es igual que el horror purgativo frente a la tragedia." ${ }^{47}$ Desconcertado o purgativo, moral o amoral, de cualquier modo, ambos enfoques han cumplido con su cometido. En este punto culmina la labor del escritor, tanto Fonseca como Hinojosa han dejado claro que la violencia puede, a través de todo lo dicho, manifestarse como fuerza creadora, como el eje de una propuesta narrativa que, ya sea desde la realidad o del absurdo, sugiere una nueva forma de concebir al mundo pero sobre todo, de entender y abordar la literatura; sus personajes, héroes o fantoches consiguieron conducirnos hacia los efectos catárticos... hasta aquí su papel; toca ahora al lector engranar todas las piezas y continuar con este proceso que persigue como fin último resignificar la violencia hasta devolverle la naturaleza sagrada que alguna vez detentó, para con esto erigirla en su propia redentora.

Este movimiento definitivo toma como punto de partida el presupuesto señalado por Iser:

Evidentemente existe una tendencia inquebrantable a participar, como lector, en los riesgos fictivos de los textos, de abandonar las seguridades

\footnotetext{
${ }^{45}$ Cardona, op. cit., p. 46.

46 José Luis Espinosa, "Francisco Hinojosa presenta hoy sus Cuentos héticos", Unomásuno, 29 de agosto de 1996, p. 24.

${ }^{47}$ Cardona, op. cit., p. 53
} 
propias para entrar en otras formas de pensamiento y de comportamiento, que de ninguna manera deben de ser de una naturaleza edificante. El lector puede salirse de su mundo, caer bajo él, vivir cambios catastróficos, sin tener consecuencias. Pues la falta de consecuencias de los textos fictivos hace posible realizar aquellas formas de autoexperiencia que son impedidas siempre por las presiones de la vida cotidiana. ${ }^{48}$

Sin consecuencias, es decir que cada uno puede, si así lo desea, mostrarse sombríamente cursi como el personaje de "Corações solitários", o pasear por las calles de Rio de Janeiro en busca de prostitutas o... cometer todos los crímenes de El Cobrador; asimismo, es factible enflaquecer mientras se come, instalar una fábrica de bombas o asesinar a la vecina de arriba. De esta suerte, el espacio literario se transforma en uno de los pocos medios capaces de sustituir el ejercicio del hecho violento por una experiencia fictiva, pero por igual intensa; en otras palabras, tal vez ninguno de nosotros se atreva a matar, en cambio puede perfectamente disfrutar la lectura de un cuento signado por la brutalidad y la agresión; de tal forma el acto de lectura se presenta como una especie de liberación, de proceso que hace las veces de válvula de escape, equivalente en mucho a la catarsis provocada por la tragedia griega. Llevando este supuesto al límite se podría decir que la fascinación que ejercen relatos de este tipo semeja la que en la antigüedad demostraban los asistentes a un sacrificio que, además de liberarlos del impulso de matar, los aproximaba de nuevo a sus dioses. Aceptémoslo o no, nos guste o no, el hombre contemporáneo acumula día con día cada vez más furia y resentimiento ¿quién o qué puede frenar esta fuerza que amenaza con destruir cuanto se ponga delante? Ante la falta del sacrificio que la reivindique, poco a poco la violencia termina por imponerse.

La ineficacia de otros recursos obliga a recurrir al lenguaje como la vía necesaria para religar al hombre moderno con el universo sagrado,

48 Wolfang Iser, "La estructura apelativa de los textos", en Dietrich Rall [comp.], En busca del texto. Teoría de la recepción literaria, México, UNAM, 1993, p. 119. 
ámbito donde los dioses y los mortales conviven gracias a que estos últimos han logrado, no sólo contener la furia de los primeros a través del sacrificio, sino sobre todo, debido a que dicho sacrificio somete al principal causante del caos y la destrucción: el propio ser humano. Reconciliación urgente del hombre con su conciencia y aun con su misma naturaleza, la violencia transformada en una experiencia estética y en gran parte sagrada, no significa que a través de su lectura sea posible erradicar la destrucción y la muerte; supone tan sólo que, por un instante, seamos capaces de disfrutar incluso de aquellas sensaciones que, desde siempre, acompañan y en mucho definen al hombre: el miedo y el odio. 